\title{
PENGGUNAAN MODUL PEMBELAJARAN PENJUMLAHAN DAN PENGURANGAN BILANGAN BULAT DENGAN PENDEKATAN CTL (CONTEXTUAL TEACHING AND LEARNING) UNTUK MENINGKATKAN PEMAHAMAN KONSEP SISWA KELAS IV SEKOLAH DASAR
}

\author{
Dyah Tri Wahyuningtyas \\ Universitas Kanjuruhan Malang \\ E-mail: dyahtriwahyu@unikama.ac.id \\ Raddin Nur Shinta \\ Universitas Kanjuruhan Malang
}

\begin{abstract}
Abstrak
Permasalahan yang sering dialami siswa sekolah dasar yaitu kesulitan dalam melakukan operasi penjumlahan dan pengurangan yang melibatkan bilangan bulat negatif. Penggunaan buku paket dari pemerintah dan LKS hanya memuat soal-soal rutin yang hanya mengembangkan pengetahuan dan kecepatan siswa dalam berhitung tetapi belum mengembangkan keterampilan berfikir kritis dan kreatif mereka. Dampak dari penggunaan bahan ajar tersebut siswa kesulitan dalam memahami materi bilangan bulat. Penelitian ini bertujuan untuk mendiskripsikan pembelajaran dengan menggunakan modul pembelajaran penjumlahan dan pengurangan bilangan bulat dengan pendekatan CTL yang dapat meningkatkan pemahaman konsep siswa kelas IV Sekolah Dasar. Metode yang digunakan dalam penelitian ini yaitu penelitian tindakan kelas dengan subjek penelitian yaitu 20 siswa kelas IVB SDN Kotalama 1 Malang. Produk penelitian ini berupa rancangan pembelajaran dengan menggunakan modul pembelajaran penjumlahan dan pengurangan bilangan bulat dengan pendekatan CTL. Hasil penelitian menunjukkan penggunaan modul pembelajaran penjumlahan dan pengurangan bilangan bulat dengan pendekatan CTL dapat meningkatkan pemahaman konsep siswa kelas IV SDN Kotalama 1 Malang dengan presentase keberhasilan yang telah ditetapkan peneliti tercapai pada siklus II yaitu persentase ratarata skor hasil tes akhir meningkat dari $70 \%$ menjadi $85 \%$, hal ini menunjukkan bahwa pemahaman konsep siswa semakin baik.
\end{abstract}

Kata Kunci: Modul, CTL, bilangan bulat, pemahaman konsep

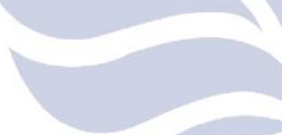

\section{Abstract}

Problems that are often experienced by elementary school students are difficulties in doing addition and subtraction operations involving negative integers. The use of government textbooks and worksheets contain only routine matters which only develop their knowledge and speed of students in math but have yet to develop critical thinking skills and their creative. The impact of the use of the instructional materials students difficulties in understanding the material integers. This study aimed to describe the learning by using learning modules addition and subtraction of integers with CTL approach that may improve understanding of the concept of Elementary School fourth grade students. The method used in this research is a classroom action research with research subjects are 20 of IV grade SDN Kotalama 1 Malang. The products of this research is the design of learning by using learning modules addition and subtraction of integers with CTL approach. The results showed the use of learning modules addition and subtraction of integers with CTL approach can improve understanding of the concept of fourth grade students of SDN Kotalama 1 Malang with a percentage of success that has been established researchers reached the second cycle is the average percentage score of final test results increased from $70 \%$ to $85 \%$, this indicates that the better students' understanding of the concept..

Keywords: Module, CTL, Integer, understanding of the concept

\section{PENDAHULUAN}

Matematika merupakan ilmu universal yang mendasari perkembangan teknologi modern, mempunyai peran penting dalam berbagai disiplin dan memajukan daya pikir manusia. Matematika perlu dibelajarkan kepada semua peserta didik mulai dari sekolah dasar untuk membekali mereka dengan kemampuan berfikir logis, analitis, sistematis, kritis, dan kreatif, serta kemampuan berkerjasama (BSNP: 2006). Untuk mencapai kompetensi tersebut diperlukan proses belajar mengajar yang maksimal. Salah satunya dicapai dengan pemberian soal-soal non rutin seperti open endeed dan problem possing. Pengajuan masalah (problem possing) dapat merangsang peningkatan matematika siswa karena siswa perlu membaca suatu informasi yang diberikan dan 
mengomunikasikan pertanyaan tersebut secara verbal maupun tertulis. Untuk mengembangkan keterampilan berfikir kritis dan kreatif pada siswa harus dimulai sejak dini agar mereka terbiasa memecahkan masalah yang akan sangat berguna dalam kehidupannya.

Bilangan adalah salah satu aspek yang dikembangkan pada mata pelajaran matematika di tingkat sekolah dasar. Pengenalan bilangan dimulai dari pengenalan bilangan asli, bilangan cacah, dan kemudian bilangan bulat. Terkait dengan pembelajaran bilangan bulat, siswa kelas IV SDN Kotalama 1 Malang masih mengalami kesulitan dalam melakukan operasi penjumlahan dan pengurangan yang melibatkan bilangan bulat negatif serta kesulitan dalam membandingkan dua bilangan bulat. Untuk mengatasi hal itu maka diperlukan suatu langkah-langkah penanaman konsep yang membimbing siswa untuk menemukan sendiri makna dari bilangan bulat negatif dan menghubungkannya dengan bilangan asli yang telah mereka pelajari sebelumnya. Dengan demikian siswa akan dapat memahami dengan betul dan tidak hanya sekedar menghafal. Faktor inilah yang biasanya sering diabaikan dalam membuat sebuah bahan ajar.

Matematika bukanlah ilmu menghafal saja, sehingga konsep dasar harus benar-benar dibangun dalam pikiran anak. Misalkan dalam membelajarkan penjumlahan $6+(-2)$ sebaiknya anak tidak langsung diberi tahu bahwa apabila penjumlahan dengan bilangan negatif akan sama dengan pengurangan atau positif $(+)$ kali negatif (-) akan sama dengan negatif (-). Dalam membelajarkan materi ini, guru bisa menganalogikan bilangan negatif dengan hutang atau dengan menggunakan arah yang berlawanan pada garis bilangan sehingga konsep tentang bilangan negatif akan lebih melekat pada diri anak dan tidak sekedar menghafal, meskipun pada tingkat lanjut secara tidak langsung siswa akan hafal dengan sendirinya.

Penanaman konsep kepada siswa juga harus disesuaikan dengan karakteristik siswa tersebut. Siswa kelas IV SD berusia antara 10-11 tahun yang dalam teori perkembangan kognitif Piaget berada pada tahap operasional konkrit, dimana siswa mulai mampu berfikir logik namun masih sebatas konkret. Materi matematika yang mengandung kata-kata atau ide abstrak akan mudah dipahami oleh siswa jika sebelumnya mereka diberikan contoh konkret dari lingkungan sekitar. Selain itu pada rambu-rambu kurikulum pembelajaran matematika disebutkan bahwa untuk mengajarkan konsep matematika dapat dimulai dengan masalah yang sesuai dengan kondisi (contextual problem). Pengetahuan bukanlah seperangkat fakta-fakta, konsep, atau kaidah yang siap untuk diingat dan diambil. Manusia harus mengkonstruksi pengetahuan itu dan memberi makna melalui pengalaman nyata. Oleh karena itu, dalam CTL, strategi untuk membelajarkan siswa menghubungkan antara setiap konsep dengan kenyataan merupakan unsur yang diutamakan dibandingkan dengan penekanan terhadap seberapa banyak pengetahuan yang harus diingat oleh siswa.

Contextual Teaching and Learning (CTL) adalah sebuah sistem yang menyeluruh dan terdiri dari bagian-bagian yang saling terhubung. Jika bagian-bagian ini terjalin satu sama lain, maka akan dihasilkan pengaruh yang melebihi hasil yang diberikan bagian-bagiannya secara terpisah. Johnson mengatakan bahwa pembelajaran kontekstual adalah sebuah sistem yang merangsang otak untuk menyusun pola-pola yang mewujudkan makna. Pembelajaran kontekstual adalah suatu sistem pembelajaran yang cocok dengan otak yang menghasilkan makna dengan menghubungkan muatan akademis dengan konteks kehidupan sehari-hari siswa. Pembelajaran kontekstual adalah usaha untuk membuat siswa aktif dalam memompa kemampuan diri tanpa merugi dari segi manfaat, sebab siswa berusaha mempelajari konsep sekaligus menerapkan dan mengaitkannya dengan dunia nyata.

Sistem CTL dalam Johnson (2002: 24) terdiri dari 8 komponen yaitu: (1) membuat keterkaitan yang bermakna (making meaningful connections); (2) mengerjakan pekerjaan yang berarti (doing significant work); (3) melakukan proses belajar yang diatur sendiri (self regulated learning); (4) Bekerja sama (collaborating); (5) berfikir kritis dan kreatif (critical and creative thingking); (6) memberikan layanan secara individual (nurturing the individual); (7) mengupayakan pencapaian standar yang tinggi (reaching high standards); (8) menggunakan penilaian autentik (using authentic assessment)

Landasan filosofi CTL adalah konstruktivisme, yaitu filosofi belajar yang menekankan bahwa belajar tidak hanya sekedar menghafal. Siswa harus mengonstruksi pengetahuan di benak mereka sendiri. Salah satu konsep utama dalam teori pembelajaran konstruktivis ialah visi siswa ideal sebagai pebelajar yang mandiri (self regulated learner). Pebelajar yang mandiri adalah siswa yang mempunyai pengetahuan tentang strategi pembelajaran yang efektif dan bagaimana serta kapan menggunakannya (Alexander, 2006; Boekaerts, 2006; Schunk\&Zimmerman, 2006; Wigfield, dkk., 2006) (dalam Santrock, 2009: 334). Pembelajaran yang mandiri ini sejalan dengan bergesernya peran guru dari perannya sebagai sumber utama dalam pembelajaran menjadi fasilitator pembelajaran.

Untuk memaksimalkan kemandirian siswa tersebut diperlukan suatu bahan belajar mandiri yang terstruktur, salah satunya dicapai melalui pemberian modul pembelajaran yang berkualitas. Modul adalah bahan ajar yang disusun secara sistematis dan menarik yang mencakup isi materi, metode, dan evaluasi yang dapat digunakan secara mandiri. Modul digunakan secara mandiri, belajar sesuai dengan kecepatan masing-masing individu secara efektif dan efesien dan memiliki karakteristik stand alone yaitu modul dikembangkan tidak tergantung pada media lain dimana salah satu karakteristiknya yaitu materi pada modul dikembangkan secara up to date dan kontekstual.

Bahan ajar merupakan kebutuhan pokok bagi guru maupun siswa sebagai pedoman dalam kegiatan pembelajaran sehingga dapat mencapai kompetensi yang diharapkan. Terkait dengan pengembangan bahan ajar, saat ini pengembangan bahan ajar dalam bentuk modul dapat memberikan kontribusi yang besar karena dapat 
mewujudkan pembelajaran yang berkualitas. Penerapan modul dapat mengkondisikan kegiatan pembelajaran lebih terencana dengan baik, mandiri, tuntas dan dengan hasil (output) yang jelas (Depdiknas, 2006). Pembelajaran dengan bantuan modul telah terbukti dapat meningkatkan kualitas proses dan hasil belajar. Andriani (2011) dalam tesisnya melaporkan bahwa pembelajaran dengan modul telah memberikan kontribusi yang signifikan terhadap peningkatan dan perolehan hasil belajar siswa.

Hasil pengamatan peneliti di SDN Kotalama 1 Malang diperoleh data bahwa di sekolah tersebut masih menggunakan buku paket dari pemerintah dan LKS yang masih bersifat drill soal. Karakteristik dari bahan ajar yang digunakan antara lain: (1) hanya berisi rangkuman materi; (2) berisi soal-soal rutin; (3) tampilan kurang menarik; (4) bahasa yang digunakan tidak komunikatif; (5) tidak ada umpan balik. Soal-soal yang ada pada LKS tersebut hanya memuat soal-soal rutin yang hanya mengembangkan pengetahuan dan kecepatan siswa dalam berhitung tetapi belum mengembangkan keterampilan berfikir kritis dan kreatif mereka. Dampak dari penggunaan bahan ajar tersebut siswa kesulitan dalam memahami materi bilangan bulat. Selain itu kondisi pembelajaran yang bersifat tradisonal di sekolah tersebut juga akan membuat siswa tidak berkembang secara maksimal. Siswa yang berkemampuan tinggi dan memiliki kecepatan tinggi dalam menyelesaikan pekerjaannya cenderung merasa bosan karena mereka harus menunggu teman lainnya untuk mempelajari materi berikutnya. Mereka juga cenderung untuk ramai dan mengganggu teman lainnya.

Untuk mengatasi permasalahan yang muncul tersebut maka dibutuhkan suatu strategi pembelajaran yang dapat memfasilitasi setiap siswa untuk mengembangkan kemampuan mereka, salah satunya yaitu dengan pemberian modul yang bersifat mandiri dan kontekstual yang didalamnya diberikan aktivitas-aktivitas yang menuntut siswa untuk aktif dan mengembangkan keterampilan berfikir kritis dan kreatif mereka.

Tujuan penelitian ini adalah untuk mendiskripsikan pembelajaran dengan menggunakan modul pembelajaran penjumlahan dan pengurangan bilangan bulat dengan pendekatan CTL yang dapat meningkatkan pemahaman konsep siswa kelas IV Sekolah Dasar. Pada penelitian ini kriteria keberhasilan pemahaman siswa dikatakan meningkat jika $\geq 75 \%$ siswa mencapai skor minimal 75 skor tertinggi 100).

\section{METODE}

Metode penelitian penggunaan modul pembelajaran penjumlahan dan pengurangan bilangan bulat dengan pendekatan CTL untuk meningkatan pemahaman konsep siswa kelas IV sekolah dasar adalah Penelitian Tindakan Kelas (PTK) dengan subyek 20 siswa kelas IV SDN Kotalama 1 Malang. Model penelitian tindakan kelas yang digunakan dalam penelitian ini adalah model alur penelitian tindakan kelas yang dikembangkan oleh Kemmis dan Mc.Taggart.
Tahap-tahap penelitian ini terdiri atas (1) penetapan fokus penelitian yaitu peneliti meminta ijin penelitian, melakukan observasi awal, memberikan cek kemampuan awal pada siswa, memvalidasi perangkat pembelajaran dan instrumen penelitian kepada validator (2) perencanaan yaitu menyiapkan dan menyusun instrumen penelitian, (3) pelaksanaan tindakan yaitu mengimplementasikan Rencana Pelaksanaan Pembelajaran (RPP) dengan menggunakan modul pembelajaran penjumlahan dan pengurangan bilangan bulat dengan pendekatan CTL serta mengadakan ulangan harian, (4) observasi dan interpretasi yaitu merekam kegiatan pembelajaran siswa selama proses pemberian tindakan dan melakukan wawancara, (5) analisis dan refleksi yaitu menganalisis tingkat pemahaman konsep siswa berdasarkan jawaban siswa pada tes akhir dan menghitung skor rata-rata siswa, mendeskripsikan data dari hasil observasi dan wawancara dan merefleksi apa yang belum dilakukan dan apa perlu disempurnakan. Hasil refleksi ini akan digunakan untuk perbaikan pada siklus berikutnya. Bentuk instrumen penelitian yang akan digunakan dalam penelitian adalah sebagai berikut: (1) soal ulangan harian, (2) lembar observasi, (3) wawancara, (4) lembar validasi.

Setelah data yang terdiri dari lembar observasi kegiatan guru, lembar observasi kegiatan siswa, hasil tes awal dan tes akhir, serta hasil wawancara sudah terkumpul, proses selanjutnya adalah melakukan analisis. Tahapan analisis data yang digunakan dalam penelitian ini terdiri dari 3 tahap yaitu (1) mereduksi data yaitu mendeskripsikan prosedur keterlaksanaan pembelajaran menggunakan modul pembelajaran penjumlahan dan pengurangan bilangan bulat dengan pendekatan CTL mengelompokkan tingkat pemahaman konsep dalam penelitian ini melalui hasil tes siswa, (2) menyajikan data yaitu membuat grafik untuk mengetahui sebaran data tentang hasil tes siswa, (3) menarik kesimpulan dan verifikasi data yaitu mengecek keberhasilan penelitian berdasarkan kriteria keberhasilan yang telah ditetapkan dan memeriksa kesalahan siswa dalam memahami konsep pada hasil tes tiap butir soal. Peneliti selanjutnya mengadakan verifikasi atau menanyakan kepada siswa yang masih banyak melakukan kesalahan pada tes tentang letak kesalahan dan kesulitan pada tes tersebut. Pada penelitian ini penarikan kesimpulan dan verifikasi dilakukan terhadap hasil pemahaman konsep siswa pada saat tes. Kemudian hasil penarikan kesimpulan dan verifikasi ini akan menentukan perlu atau tidaknya peneliti melakukan siklus berikutnya.

\section{HASIL DAN PEMBAHASAN}

Modul pembelajaran yang disusun dengan pendekatan CTL menyediakan aktivitas yang mendorong siswa untuk membuat kesimpulan sendiri tentang konsep matematika yang dipelajari. Modul juga dilengkapi dengan kunci jawaban agar siswa dapat mengetahui secara langsung jawaban yang benar tanpa menunggu pembahasan. Dari pekerjaan siswa tersebut kemudian 
guru memberikan catatan tentang waktu pengumpulan tugas dan hasilnya. Beberapa catatan sebagai umpan balik terhadap pekerjaan siswa juga dapat dituliskan pada tempat yang telah disediakan yaitu di bawah aktivitas yang dikerjakan.

Modul yang akan disusun terdiri dari kata pengantar, deskripsi modul, petunjuk penggunaan modul, daftar isi, pendahuluan, cek kemampuan awal, penyampaian materi yang dibagi menjadi dua kelompok besar yang masing-masing dilengkapi dengan uji kompetensi, ulangan harian, dan kunci jawaban. Cek kemampuan awal harus dikerjakan oleh siswa agar mereka mengetahui kemampuan awal yang dimiliki terkait dengan bilangan bulat sebelum mempelajari lebih lanjut.

Empat kompetensi dasar yang akan dibahas pada modul ini terbagi menjadi dua kelompok besar yaitu KD 5.1 mengurutkan bilangan bulat akan membahas tentang mengenal bilangan bulat, himpunan bilangan bulat, membandingkan dua bilangan bulat, mengurutkan bilangan bulat, dan bilangan bulat pada garis bilangan. Kelompok berikutnya yaitu KD 5.2 sampai KD 5.4 terkait dengan penjumlahan dan pengurangan bilangan bulat.

Materi dituliskan dalam bentuk aktivitas yang mengarahkan siswa untuk dapat membuat kesimpulan tentang konsep yang dipelajari. Materi pengenalan bilangan negatif dituliskan melalui contoh-contoh dalam kehidupan sehari-hari. Untuk mengembangkan pemikiran kritis dan kreatif siswa, beberapa masalah dibentuk dalam open endeed dan problem possing. Setiap aktivitas diengkapi dengan kolom penilaian dan catatan guru. Kolom ini berfungsi untuk menuliskan hasil pekerjaan siswa setelah mereka mengecek sendiri jawaban mereka dari kunci jawaban yang telah disediakan dan untuk menuliskan catatan guru sebagai umpan balik dari aktivitas yang telah dikerjakan. Penilaian otentik dimunculkan pada kolom tersebut, dimana waktu pengumpulan dan hasil pekerjaan siswa terekam pada kolom tersebut sehingga perkembangan pekerjaan siswa dapat diketahui.

Aktivitas yang diberikan didasarkan pada pendekatan CTL dimana unsur-unsurnya yaitu penggunaan contoh dalam kehidupan sehari-hari dalam penyampaian materi, pengaturan diri yang dituangkan dalam bentuk problem possing, berfikir kritis dan kreatif yang dicapai melalui pemberian masalah dalam bentuk open ended dengan ada unsur kolaborasi, menuntun siswa dalam menemukan sendiri suatu konsep yang dipelajari, serta penggunaan penilaian otentik dengan pemberian kolom penilaian pada modul untuk mencatat hasil kerja siswa. Sebagai pengukur ketuntasan belajar siswa, selain melalui permasalahan dalam aktivitasaktivitas yang diberikan, modul juga dilengkapi dengan uji kompetensi.

Komponen CTL pada modul pembejaran penjumlahan dan pengurangan bilangan bulat terhadap aktivitas pembelajaran siswa di SDN Kotalama 1 Malang yaitu:

\begin{tabular}{|c|c|c|}
\hline $\begin{array}{l}\text { Komponen } \\
\text { CTL }\end{array}$ & $\begin{array}{l}\text { Komponen } \\
\text { CTL }\end{array}$ & Aktivitas Siswa \\
\hline $\begin{array}{l}\text { Making } \\
\text { meaningfull } \\
\text { connections }\end{array}$ & $\begin{array}{l}\text { Making } \\
\text { meaningfull } \\
\text { connections }\end{array}$ & $\begin{array}{l}\text { Mencermati contoh } \\
\text { yang diberikan dan } \\
\text { menemukan contoh } \\
\text { lain dari penggunaan } \\
\text { bilangan bulat dalam } \\
\text { kehidupan sehari-hari }\end{array}$ \\
\hline $\begin{array}{l}\text { Self regulated } \\
\text { learning }\end{array}$ & $\begin{array}{l}\text { Self regulated } \\
\text { learning }\end{array}$ & $\begin{array}{l}\text { Mengaitkan informasi } \\
\text { yang diberikan untuk } \\
\text { membentuk soal } \\
\text { kemudian } \\
\text { menyelesaikannya }\end{array}$ \\
\hline Collaborating & Collaborating & $\begin{array}{l}\text { Berdiskusi } \\
\text { temannya tengan } \\
\text { dengan soal open } \\
\text { endeed dan saling } \\
\text { memeriksa jawaban }\end{array}$ \\
\hline $\begin{array}{l}\text { Critical and } \\
\text { creative } \\
\text { thingking }\end{array}$ & $\begin{array}{l}\text { Pemberian } \\
\text { masalah dalam } \\
\text { bentuk open- } \\
\text { ended }\end{array}$ & $\begin{array}{l}\text { Menyelesaikan } \\
\text { masalah dengan } \\
\text { beberapa cara dan } \\
\text { membandingkan } \\
\text { jawabannya dengan } \\
\text { jawaban temannya } \\
\text { untuk kemudian } \\
\text { menarik kesimpulan } \\
\text { dari jawaban-jawaban } \\
\text { tersebut }\end{array}$ \\
\hline $\begin{array}{l}\text { Nurturing } \\
\text { individual }\end{array}$ & $\begin{array}{l}\text { Pemberian cek } \\
\text { kemampuan } \\
\text { awal untuk } \\
\text { siswa serta } \\
\text { bimbingan } \\
\text { yang tertuang } \\
\text { dalam modul } \\
\text { untuk dapat } \\
\text { membuat } \\
\text { kesimpulan } \\
\text { dari materi } \\
\text { yang dipelajari }\end{array}$ & $\begin{array}{lr}\text { Melakukan } & \text { penilaian } \\
\text { terhadap } & \text { hasil } \\
\text { belajarnya } & \text { dan } \\
\text { kemudian mengikuti } \\
\text { petunjuk yang ada } \\
\text { untuk melanjutkan } \\
\text { belajarnya atau } \\
\text { mengulangi serta } \\
\text { belajar } \\
\text { membuat kesimpulan }\end{array}$ \\
\hline $\begin{array}{l}\text { Reaching } \\
\text { high standar } \\
\text { and using } \\
\text { authentic } \\
\text { assessment }\end{array}$ & $\begin{array}{l}\text { Pemberian } \\
\text { kolom } \\
\text { penilaian } \\
\text { secara mandiri } \\
\text { terhadap hasil } \\
\text { belajar siswa }\end{array}$ & $\begin{array}{lr}\text { Menilai } & \text { hasil } \\
\text { belajarnya } & \text { secara } \\
\text { mandiri } & \text { setelah } \\
\text { menjawab } & \text { uji } \\
\text { kompetensi } & \text { yang } \\
\text { diberikan } & \text { serta } \\
\text { memeriksa tugas- } \\
\text { tugas yang ada pada } \\
\text { modul serta guru } \\
\text { memberikan catatan- } \\
\text { catatan terhadap hasil } \\
\text { pekerjaan siswa }\end{array}$ \\
\hline
\end{tabular}

Berdasarkan 6 komponen CTL yang diterapkan pada modul pembelajaran penjumlahan dan penguarangan bilangan bulat pada penelitian ini telah sejalan dengan sistem CTL dalam Johnson (2002: 24) yang terdiri dari 8 komponen yaitu: (1) membuat keterkaitan yang bermakna (making meaningful connections); (2) mengerjakan pekerjaan yang berarti 
(doing significant work); (3) melakukan proses belajar yang diatur sendiri (self regulated learning); (4) Bekerja sama (collaborating); (5) berfikir kritis dan kreatif (critical and creative thingking); (6) memberikan layanan secara individual (nurturing the individual); (7) mengupayakan pencapaian standar yang tinggi (reaching high standards); (8) menggunakan penilaian autentik (using authentic assessment).

Secara umum, langkah-langkah pembelajaran dengan menggunakan modul pembelajaran penjumlahan dan pengurangan bilangan bulat dengan pendekatan CTL yaitu:

1. Tahap awal, guru memberikan modul pembelajaran penjumlahan dan pengurangan bilangan bulat dan menjelaskan petunjuk penggunaan modul serta mengarahkan siswa untuk membaca modul pada bagian awal. Pada tahap awal guru mengarahkan siswa mengerjakan cek kemampuan awal pada bagian awal modul untuk mengetahui kemampuan awal siswa pada materi sebelumnya yaitu mengenal bilangan bulat.

2. Tahap inti, guru membimbing siswa untuk mulai mengerjakan kegiatan yang ada pada modul pembelajaran penjumlahan dan pengurangan bilangan bulat. Kegiatan pada modul diawali dengan penggunaan media pembelajaran yang telah dilampirkan pada modul yaitu chip berwarna. Kegiatan siswa dengan menggunakan media chip berwarna yaitu menentukan penjumlahan dan pengurangan bilangan bulat dengan menempelkan chip berwarna sesuai dengan ketentuan pada kolom yang tersedia pada modul. Pada akhir kegiatan penggunaan media chip berwarna, siswa diarahkan untuk memberikan kesimpulan dari pengetahuan yang telah ditemukan. Selanjutnya siswa dapat mengerjakan latihan soal tanpa menggunakan media pembelajaran. Pada tahap ini guru sebagai fasilitator yang mengarahkan siswa untuk memahami materi penjumlahan dan pengurangan bilangan bulat.

3. Tahap akhir, guru mengarahkan siswa untuk menukarkan modul pembelajaran yang telah dikerjakan kepada teman sebangku untuk mengecek jawaban pada kunci jawaban yang tersedia. Selanjutnya guru bersama siswa membahas kegiatan pada modul pembelajaran yang telah dikerjakan. Pada akhir pembelajaran guru membimbing siswa untuk memberikan kesimpulan pada pembelajaran penjumlahan dan pengurangan bilangan bulat.

Tahapan yang telah dirancang secara garis besar sesuai dengan tahapan perkembangan berfikir siswa yang dinyatakan oleh Bruner (1965:11) yaitu (1) Enactive, pada tahap ini anak-anak belajar dengan menggunakan atau memanipulasi media chip berwarna yang tersedia pada modul secara langsung. Anak menempelkan media chip pada kolom yang tersedia sesuai dengan soal, (2) Ikonic, pada tahap ini kegiatan anak mulai mengaitkan mental yang merupakan gambaran dari objek. Siswa mentranlasi peggunaan media chip berwarna ke dalam symbol angka dan (3) Symbolic, pada tahap ini merupakan tahap memanipulasi simbol-simbol secara langsung. Siswa telah mampu menggunakan notasi untuk menyelesaikan penjumlahan dan pengurangan bilangan bulat.

Pemahaman siswa tentang konsep penjumlahan dan pengurangan bilangan bulat sangat baik. Hal ini terlihat berdasarkan hasil ulangan harian siswa. Ulangan harian siswa dilaksanakan dengan tujuan untuk mengetahui tingkat pemahaman konsep siswa terhadap materi penjumlahan dan pengurangan bilangan bulat serta mengetahui keberhasilan siswa. Ulangan harian dilakukan pada akhir siklus I dan siklus II yang dikerjakan siswa secara individu. Soal ulangan harian diberikan setelah modul pembelajaran penjumlahan dan pengurangan bilangan bulat telah selesai dikerjakan. Adapun kriteria khusus bahwa pemahaman konsep siswa dikatakan meningkat jika $\geq 75 \%$ siswa mencapai nilai KKM 75 (skor tertinggi 100). data yaitu

Berdasarkan hasil tes akhir kelas $\mathrm{V}$, diperoleh

1. Pada siklus I sebanyak 14 siswa atau $70 \%$ siswa yang memperoleh nilai KKM (Kriteria Ketuntasan Minimal) yaitu 75 .

2. Pada siklus II sebanyak 17 siswa atau $85 \%$ siswa yang memperoleh nilai KKM (Kriteria Ketuntasan Minimal) yaitu 75 .

Data di atas menunjukkan bahwa pemahaman konsep penjumlahan dan pengurangan bilangan bulat siswa mengalami peningkatan dari siklus I ke siklus II yaitu meningkatkan presentase siswa yang mencapai KKM. Pada siklus I presentase siswa kelas IV yang mencapai KKM sebesar dan $70 \%$, kemudian pada siklus II presentase siswa kelas IV yang mencapai KKM meningkat menjadi $85 \%$.

Hasil wawancara dengan beberapa siswa terkait dengan penggunaan modul pembelajaran penjumlahan dan pengurangan bilangan bulat dengan pendekatan CTL ini menunjukkan bahwa siswa tidak mengalami kesulitan dan merasa nyaman dalam membentuk pengalaman belajarnya, sehingga siswa lebih mudah dalam memahi materi penjumlahan dan pengurangan bilangan bulat. Meskipun demikian masih ada beberapa siswa yang merasa kesulitan pada bagian-bagian tertentu dari modul.

\section{PENUTUP}

\section{Simpulan}

U C Berdasarkan penelitian yang telah dilakukan mengenai penggunaan modul pembelajaran penjumlahan dan pengurangan bilangan bulat dengan pendekatan CTL untuk meningkatkan pemahaman siswa kelas IV sekolah dasar dapat disimpulkan bahwa pembelajaran dengan menggunakan modul terdiri dari 4 tahap yaitu: (1) Tahap awal, guru mengarahkan siswa mengerjakan cek kemampuan awal pada bagian awal modul untuk mengetahui kemampuan awal siswa dan pengetahuan pada materi sebelumnya. (2) tahap inti, guru membimbing siswa untuk mengerjakan kegiatan yang ada pada modul pembelajaran penjumlahan dan pengurangan bilangan bulat. Pada tahap ini guru sebagai fasilitator untuk mengarahkan siswa dalam memahami materi penjumlahan dan pengurangan bilangan bulat dengan dan tanpa media chip berwarna yang ada pada 
modul. (4) Tahap akhir, guru bersama siswa membahas kegiatan modul yang telah dikerjakan serta membimbing siswa untuk memberikan kesimpulan terhadap pembelajaran penjumlahan dan pengurangan bilangan bulat yang telah dilaksanakan.

Penggunaan modul pembelajaran penjumlahan dan pengurangan bilangan bulat dengan pendekatan CTL dapat meningkatkan pemahaman konsep siswa kelas IV SDN Kotalama 1 Malang dengan presentase peningkatan pemahaman konsep adalah sebagai berikut: Pada pencapaian kriteria keberhasilan dari ulangan harian ditunjukkan pada persentase rata-rata skor hasil ulangan harian meningkat dari $70 \%$ menjadi $85 \%$; hal ini menunjukkan bahwa pemahaman konsep siswa semakin baik.

\section{Saran} mengembangkan bahan ajar pembelajaran dalam bentuk modul pembelajaran inovatif serta penggunaan media pembelajaran untuk membantu pemahaman konsep matematika yang disesuaikan dengan materi dan kondisi sosial siswa. Berdasarkan penelitian yang telah dilakukan, saran untuk peneliti selanjutnya hendaknya dapat mengembangkan penelitian lebih lanjut tentang proses pembelajaran menggunakan modul pembelajaran dengan pendekatan yang berbeda yang dapat meningkatkan pemahaman konsep matematika siswa.

\section{DAFTAR PUSTAKA}

Andriani, F. 2011. Pengembangan Modul Pembelajaran Kimia untuk Kelas XI Semester III Program Kejuruan Teknik Mekank Otomotif dengan Pendekatan Pembelajaran Berbasis Masalah $(P B L)$. Malang: Program Pasca Sarjana Universitas Negeri Malang.

Bruner, J. 1965. Toward a Theory of Instruction. Cambride: Harvard University Press.

Badan Standar Nasional Pendidikan. 2006. Standar Kompetensi dan Kompetensi Dasar Matematika. Jakarta: Departemen Pendidikan Nasional.

BSNP. 2006. Pengembangan bahan ajar, (Online), (http://www.google.co.id/url?sa=t\&rct=j\&q=syara tsyarat+pengembangan+bahan+ajar+menurut+bsn p).

Depdiknas. 2006. Peraturan Menteri Pendidikan Nasional Republik Indonesia (Permendiknas) Nomor 22 Tahun 2006 Tentang Standar Isi Sekolah. Jakarta: Depdiknas.

Johnson, Elaine B. 2002. Contextual Teaching and Learning: what it is and why it's here to stay. California: A Sage Publications Company.
Johnson, Elaine B. 2002. Contextual Teaching and Learning: Menjadikan Kegiatan BelajarMengajar Mengasyikkan dan Bermakna. Terjemahan oleh Ibnu Setiawan. 2009. Bandung: MLC.

Santrock, John W. 2009. Psikologi Pendidikan (Educational Psychology) (edisi 3). Jakarta: Salemba Humanika. 